\title{
Keefektifan Media Matematika Virtual Berbasis Teams Game Tournament Ditinjau Dari Cognitive Load Theory
}

\author{
Virtual Mathematics Media Effectiveness Based Teams Game Tournament Reviewed From Cognitive \\ Load Theory
}

Nuryadi, Nanang Khuzaini,

Fakultas Keguruan dan Ilmu Pendidikan, Universitas Mercu Buana Yogyakarta

* Korespondensi Penulis. E-mail: nuryadi_umb@yahoo.co.id, Telp: +6285799909816

Tujuan penelitian ini adalah untuk menghasilkan media pembelajaran matematika virtual berbasis TGT yang berkualitas baik dan layak untuk digunakan dalam pembelajaran matematika dan mendeskripsikan seberapa baik kualitas perangkat pembelajaran matematika yang dihasilkan. Kriteria kualitas yang digunakan mengacu pada kriteria Nieveen, yaitu valid, praktis dan efektif. Materi yang dikembangkan adalah materi Bangun Ruang Sisi Datar. Jenis penelitian ini adalah penelitian pengembangan (Development research). Penelitian ini mengembangkan perangkat pembelajaran matematika dengan menggunakan model pengembangan yang diadaptasi dari model pengembangan ADDIE. Tahap-tahap yang dilalui sampai diperoleh multimedia pembelajaran matematika yang valid, praktis dan efektif adalah analisis kebutuhan dan perumusan tujuan, desain/pengembangan produk, uji coba, revisi dan kajian produk akhir. Uji coba yang dilakukan meliputi ujicoba ahli/validasi ahli (expert judgement), uji coba kelompok kecil (small group try$o u t$ ) dan uji coba lapangan (field try-out). Uji coba lapangan (field try-out) dilakukan pada dua kelasVIII di SMP N 1 Sedayu. Instrumen penelitian yang digunakan adalah lembar validasi, lembar penilaian guru, lembar penilaian siswa, dan tes Cognitive Load Theory (CLT). Penelitian ini menghasilkan media pembelajaran matematika virtual yang berkualitas dan layak. Hasil penelitian menunjukkan bahwa multimedia pembelajaran matematika yang dikembangkan valid, praktis dan efektif.

Kata Kunci: media pembelajaran matematika virtual, CLT

\begin{abstract}
The purpose of this study is to produce virtual mathematics learningmedia based on good quality of TGT for use in learning mathematics and describe how well the mathematics learning tools quality which was produced. The quality criteria used refers to the Nieveen criteria, which are valid, practical and effective. The material that was developed was the material of plane geometry. This research developed a mathematics learning tool using a development model adapted from the ADDIE development model. The stages that need to be done to obtain a valid, practical and effective multimedia learning mathematics is requirement analysis and objective formulation, product design / development, trial, revision and final product study. The experiments included expert trial / expert judgment, small group try-out and field try-out. The field try-out was done on two classes of VIII grade in SMP N 1 Sedayu. The research instrument used was validation sheet, teacher's appraisal sheet, student assessment sheet, and Cognitive Load Theory (CLT) test. This research produces a qualified and viable virtual mathematics learning media. The results showed that multimedia learning mathematics which was developed is valid, practical and effective.
\end{abstract}

Keywords: Virtual Mathematics Learning Media, CLT

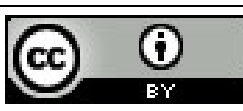

$\mathrm{W}:$ http://ejurnal.mercubuana-yogya.ac.id/index.php/mercumatika E : mercumatika@mercubuana-yogya.ac.id

DOI: http://dx.doi.org/10.26486/jm.v2i2.370 


\section{PENDAHULUAN}

Dalam kurikulum 2013 disebutkan bahwa salah satu untuk menghadapi tantangan perkembangan dan teknologi serta informasi diperlukan sumber daya manusia yang memiliki kemampuan hidup sebagai pribadi dan warga negara yang beriman, produktif, kreatif, inovatif dan afektif. Untuk itu, program pendidikan yang dikembangkan perlu menekankan kemampuan berpikir pada siswa khususnya siswa SMP. Pengembangan kemampuan berpikir ini dapat dilakukan melalui pembelajaran matematika.

Menurut Sugiman (2013:1) pembelajaran matematika yang terjadi di kelas-kelas saat ini masih cenderung pada metode penuangan pengetahuan oleh guru kepada siswanya. Secara umum guru lebih percaya diri manakala mengajarkan dengan cara memulai proses pengajaran dengan penyampaian informasi (berupa fakta; konsep, prosedur, dan terkadang juga metakognisi) dari suatu abstrak matematika. Karena objek belajar matematika adalah abstrak, maka pelajaran yang menekankan pada pemberian informasi akan menghalangi daya abstraksi siswa. Berdasarkan uraian di atas maka sangat diperlukan strategi yang mampu melibatkan siswa secara aktif dan mendorong siswa agar pertama kali termotivasi untuk belajar matematika sebelum ia memulai mengerjakan matematika.

Salah satu upaya yang bisa dilakukan adalah dengan menggunakan alat bantu komputer. Munir (2008: 232) mengemukakan bahwa komputer dulunya dipergunakan hanya sebatas pengolah data (word processing) dan alat bantu bantu menghitung, namun seiring dengan kemajuan teknologi maka komputer telah bergeser dengan kemampuannya dalam mengakses atau menjalankan program-program pembelajaran yang dikemas dalam bentuk multimedia. Bahkan komputer juga sudah dapat digunakan untuk membuat multimedia maupun alat peraga interaktif. Lebih lanjut, Munir (2008: 234) mengutip hasil penelitian eksperimen yang dilakukan oleh Edward, dkk yang berhasil mengungkapkan bahwa pembelajaran dengan menggunakan multimedia memberikan hasil yang lebih baik secara signifikan $(\alpha=0,05)$ dibanding dengan pembelajaran yang menggunakan buku teks.

Menurut Geisert (1995:71) menjelaskan bahwa multimedia merupakan kombinasi beberapa jenis media menjadi satu ke dalam satu aplikasi komputer dengan disertai aspek yang menarik minat siswa, seperti gambar, animasi, warna, grafik digital, dan suara. Namun demikian hanya 20$25 \%$ yang memenuhi syarat dan layak digunakan untuk kerperluan pendidikan (Munir, 2008). Fakta seperti ini merupakan suatu tantangan yang perlu disikapi dengan segera untuk mengembangakan media pembelajaran virtual yang menarik apalagi berbasis Teams Game Tournament (TGT). Keunggulan dalam TGT menggunakan permainan yang dapat disesuaikan dengan topik apapun. Permainan ini biasanya lebih baik daripada permainan individu, memberikan kesempatan bagi siswa untuk peduli satu sama lain dan menghindari sebuah masalah permainan individu. Jika semua siswa menggabungkan kemampuannya dalam tim, semua siswa memiliki peluang yang baik untuk sukses (Slavin, 2008:338). Dengan adanya permainan dan kompetisi 
memungkinkan siswa dapat belajar lebih rileks disamping itu dapat menumbuhkembangkan tanggungjawab, kejujuran, kepedulian, persaingan sehat dan keterlibatan siswa dalam belajar.

Mengimplementasikan Cognitive Load Theory (CLT) dalam membangun media pembelajaran virtual diharapkan dapat menghasilkan sarana pembelajaran yang efektif. Menurut CLT, efektifitas instruksional pembelajaran ditentukan oleh tiga aspek beban kognitif (cognitive load), yakni beban kognitif instrinsik (intrinsic cognitive load), beban kognitif ekstra (extraneous cognitive load), dan beban kognitif germane (germane cognitive load) (Brunning Scaw, Norby dan Ronning, 2004; Sweler, Merrienboer dan Paas, 1999; Sweller, 2004, 2010). Karena kemampuan kognitif kita untuk memproses materi yang kompleks adalah terbatas, CLT menyarankan bahwa penyajian materi sebaiknya meminimalkan intrinsic dan extraneous cognitive load, namun menstimulasi germane cognitive load. Intrinsic cognitive load berkaitan dengan tingkat kompleksitas materi yang dipengaruhi oleh tingkat pengetahuan awal yang telah dimiliki oleh siswa. Extraneous cognitive load berkaitan dengan cara penyajian informasi selama pembelajaran, apakah memuat gambar, teks, animasi atau suara, sebaiknya tidak mengakibatkan proses kognitif yang berlebihan. Penyajian informasi tersebut dapat melalui media, guru, teman, atau lingkungan siswa. Sedangkan germane cognitive load berkaitan dengan proses konstruksi pengetahuan yang baru (Brunning Scaw, Norby dan Ronning, 2004; Sweler, Merrienboer dan Paas, 1999).

Pengembangan media pembelajaran matematika virtual berbasis TGT di sekolah dengan biaya terjangkau, namun efektif dan efisien dalam menunjang pembelajaran. Penelitian untuk mewujudkan media pembelajaran matematika virtual berbasis TGT ditinjau dari CLT ini sangat urgen untuk dilaksanakan sehingga segera memfasilitasi kegiatan pembelajaran matematika di sekolah.

Teknologi pembelajaran merupakan salah satu bidang garapan yang berupaya membantu proses belajar manusia dengan jalan memanfaatkan secara optimal komponen-komponen pembelajaran melalui fungsi pengembangan dan pengelolaan (Mukminan, 2004: 8).

Pengembangan multimedia pembelajaran termasuk dalam domain "pengembangan". Domain "pengembangan" termasuk kawasan kedua yaitu "design, development, utilization, management and evaluation". Multimedia dapat dikategorikan menjadi dua yaitu linier dan nonlinier. Multimedia linier dipakai tanpa menggunakan tombol navigasi seperti halnya presentasi film, sementara multimedia non-linier penggunaannya membutuhkan interaktifitas pengguna untuk mengontrol, seperti halnya pada permainan komputer (wikipedia). Multimedia non-linier disebut juga multimedia interaktif.

Dalam pengembangan media pembelajaran matematika virtual berbasis TGT ini adalah Permainan dalam proses pembelajaran dengan pengembangan media pembelajaran virtual yang disebut Uno Beam Magic (UBM). Menurut Nurfitri (2015:4) mengemukakan bahwa Uno Beam Magic merupakan permainan yang digunakan sebagai media pemahaman siswa dalam 
Vol. 2, No. 1, Oktober 2017, pp. 57-68

pembelajaran matematika yang membuat siswa menjadi tertarik dan mudah dalam memperlajari pelajaran matematika.

Permainan ini merupakan permainan untuk melatih strategi dengan menyusun balok-balok membentuk menara, dimana setiap balok terdiri dari susunan balok dan setiap balok terdapat soalsoal tentang matematika yang membuat anak bermain sekaligus belajar pelajaran matematika. Sedangkan permainan balok itu sendiri, merupakan cikal bakal dari semua mainan edukasi, mungkin yang paling tua di dunia. Jenis dan bentuknya pun bermacam-macam, detail, dan unik.

\section{Kriteria Produk media Pembelajaran berbasis media virtual interaktif}

Media pembelajaran yang layak digunakan memiliki beberapa kriteria yang harus diketahui, menurut Romi Satria Wahono (2008: 55) ada tiga aspek kriteria produk multimedia, yaitu : (a)aspek desain pembelajaran;(b)Aspek rekayasa perangkat lunak;(c)Aspek komunikasi visual. Sedangkan menurut Lee dan Owens (2004: 118) menyatakan bahwa multimedia yang berkualitas seharusnya memiliki tema yang berhubungan dengan pemecahan masalah, batasan interaksi dan umpan balik, batasan perlakuan video dan audio, standar desain teks, standar desain grafis, dan mengatur animasi dan efek khusus digunakan untuk mendukung tujuan pembelajaran.

Kualitas multimedia berpengaruh terhadap hasil yang ingin dicapai oleh pengguna, sehubungan dengan itu Pustekkom (2004: 4) memaparkan bahwa kriteria kualitas multimedia ditinjau dari aspek media meliputi: (1) pemilihan jenis dan ukuran huruf; (2) pemilihan dan komposisi warna; (3) tampilan grafis, gambar, foto dan grafik; (4) kualitas video; (5) animasi, pengguna narasi; (6) daya dukung musik dan sound effec; (7) screen design; (8) penggunaan bahasa; (9) navigasi; (10) konsistensi tombol; (11) kemudahan menggunakan; (12) antisipasi kemungkinan respon siswa; (13) respon terhadap respon siswa; (14) kecepatan.

\section{Metode Penelitian}

Jenis dan Desain Penelitian

Penelitian ini merupakan jenis penelitian pengembangan, yaitu suatu proses penelitian yang digunakan untuk mengembangkan suatu produk. Produk yang dihasilkan dari penelitian ini berupa media pembelajaran matematika virtual berbasis TGT yaitu multimedia interaktif pada materi "Bangun Ruang Sisi Datar" untuk siswa SMP kelas VIII. Dalam penelitian pengembangan ini peneliti akan mengikuti desain pengembangan media ADDIE (Analysis, Design, Development, Implementation, Evaluation). Adapun langkah-langkah pengembangan oleh ADDIE, antara lain sebagai berikut:(1) Analisis: pada tahap ini kegiatan yang dilakukan adalah menganalisis kebutuhan dan karasteristik siswa, menganalisis kurikulum untuk menetapkan kompetensi hasil belajar, memilih dan menetapkan materi pokok yang akan dikembangkan, dan mengembangkan alat evaluasi;(2) Desain: pada tahap ini, pengembangan membuat storyboard dan flowchart;(3) Produksi: pada tahap ini dilakukan pengemasan materi ke dalam CD sesuai storyboard yang telah dibuat; (4)Implementasi : dalam tahap ini, akan dilakukan uji coba. sebelum uji coba dilaksanakan, 
dilakukan review atau validasi oleh ahli materi dan ahli media terhadap produk multimedia yang dikembangkan;(5) Kemudian dilakukan uji coba dengan langkah-langkah sebagai berikut : (a) Uji coba satu lawan satu;(b)Uji coba kelompok kecil;(c)Uji coba kelompok besar/uji coba lapangan. Revisi dilakukan setiap selesai melakukan uji coba yang berdasarkan saran dan kritik dari subyek coba; dan(6) Evaluation : dalam tahap ini akan dilakukan evaluasi media pembelajaran yang telah dibuat berdasarkan hasil angket evaluasi media pembelajaran. Berdasarkan hasil evaluasi ini selanjutnya dapat diketahui karakteristik media pembelajaran matematika virtual berbasis TGT yang diharapkan.

\section{Kualitas Produk Pengembangan}

Nieveen (1999: 127-128) mengatakan kualitas produk, pendesainan, pengembangan, dan pengevaluasian program harus memenuhi kriteria valid, praktis, dan efektif.

\section{Kevalidan Perangkat Pembelajaran}

Menurut Nieveen (1999: 127) kualitas produk dikatakan valid dilihat dari keterkaitannya dengan tujuan dari pengembangan produk itu sendiri harus benar-benar dipertimbangkan. Selanjutnya, untuk menggambarkan kriteria kevalidan produk pembelajaran yaitu apabila perangkat pembelajaran dapat menggambarkan kurikulum yang diharapkan atau intended, yakni kombinasi antara ideal dan formal.

Melakukan uji awal terhadap desain produk oleh ahli bidang pembelajaran matematika, guru mata pelajaran matematika, dan ahli media. Ahli materi dan pembelajaran matematika bertujuan untuk menilai kevalidan multimedia pembelajaran matematika dari aspek materi. Ahli materi dan pembelajaran tersebut terdiri dari orang, yaitu : Prof. Dr. Rusgianto Heri Santoso, M.Pd selaku dosen pendidikan matematika Universitas Negeri Yogyakarta.

Selain itu, karena kevalidan produk tidak hanya hanya ditinjau dari aspek materi dan pembelajaran tetapi juga ditinjau dari aspek media. Oleh karena itu untuk menilai kevalidan produk juga ditinjau dari aspek media yang dinilai oleh ahli media. Ahli media tersebut terdiri dua orang yaitu Heru Sukoco, S.Si., M.Pd dan Jaylani Susanto, S.Kom.

Uji kelompok kecil dilakukan untuk mengetahui efektifitas desain produk. Uji coba dilakukan pada 20 orang siswa kelas VIII SMP N 1 Sedayu Kabupaten Bantul yang mewakili kelompok dengan kemampuan tinggi, sedang dan kurang. Hasil uji coba berupa desain yang praktis dari sisi penggunaan.

Uji coba dilakukan pada seluruh siswa kelas VIII SMP N 1 Sedayu Kabupaten Bantul yang terdiri dari 64 siswa yang terbagi ke dalam dua kelas. Pada saat ujicoba lapangan, guru yang melaksanakan pembelajaran adalah peneliti. Ujicoba lapangan dimaksudkan untuk menilai keefektifan dan kepraktisan produk. Penilaian kepraktisan selain dinilai oleh siswa juga dinilai oleh seorang guru matematika, yaitu Drs. Sri Joko selaku guru matematika di SMP N 1 Sedayu Kabupaten Bantul. 


\section{Kepraktisan Perangkat Pembelajaran}

Vol. 2, No. 1, Oktober 2017, pp. 57-68

Nieveen (1999: 127) mengatakan bahwa kepraktisan dilihat dari pendapat oleh pengguna terutama guru dan siswa yang menganggap produk yang dihasilkan mudah untuk digunakan dan juga menggambarkan proses pembelajaran yang aktual. Ini dimaksudkan adanya kekonsistenan antara intended dan perceived curriculum dan intended and operational curriculum. Jika keduanya konsisten maka produk tersebut dikatakan praktis. Berdasarkan pendapat di atas, maka untuk tingkat kepraktisan dalam media pembelajaran matematika virtual berbasis TGT ini ditinjau dari penilaian guru dan penilaian siswa. Untuk itu aspek kepraktisan dikaitkan yaitu dengan penilaian para pengguna (guru dan siswa) menyatakan produk yang dikembangkan mudah untuk digunakan.

Data kepraktisan multimedia pembelajaran matematika diperoleh dari penilaian guru dan siswa terhadap multimedia pembelajaran matematika. Kepraktisan multimedia pembelajaran matematika yang dikembangkan diukur berdasarkan hasil penilaian dari guru dan siswa yang menggunakan produk pada saat uji coba.

Multimedia pembelajaran matematika yang dikembangkan dikatakan praktis jika penilaian kepraktisan perangkat pembelajaran oleh guru dan siswa konsisten minimal berada pada kategori baik.

\section{Keefektifan Produk}

Tingkat keefektifan menurut Nieveen (1999: 127) menggambarkan pengalaman siswa dan hasil belajar siswa. Ini berarti konsistensi antara intended and experiental curriculum dan intended and attained curriculum. Adapun kefektifan pembelajaran menurut Robert \& Dick (1996: 3) yaitu suatu pembelajaran dikatakan efektif berdasarkan data dan informasi hasil belajar yang didokumentasikan.

Menurut Kemp (1994: 228) menyatakan indeks keefektifan adalah persentase yang menjelaskan: (a) level penguasaan yang dicapai oleh siswa untuk tiap tujuan pembelajaran; (b) rata-rata pencapaian tujuan oleh semua siswa. Persentase penguasaan ditentukan oleh guru setelah melaksanakan pembelajaran. Lebih lanjut dikatakan bahwa batas penguasaan standar keberhasilan adalah 75\%, sebagaimana yang ditentukan BSNP (2006: 12) bahwa kriteria ideal ketuntasan untuk masing-masing indicator adalah $75 \%$.

\section{Analisis Data}

Data yang diperoleh dari angket validasi ahli dianalisis berdasarkan langkah-langkah berikut: (1)Penilaian oleh ahli dirangkum dalam satu tabel yang disebut tabel hasil penilaian kelayakan produk; (2) Pemeriksaan terhadap setiap hasil penilaian oleh ahli;(3) Mengolah data pada masing-masing aspek yang dinilai yang meliputi: aspek kognitif Intrinsik, aspek kognitif ekstra, aspek kualitas materi matematika, aspek Syarat Didakdik, aspek Syarat Konstruksi, dan aspek Syarat Teknis; dan (4) Membuat kriteria hasil penilaian sebagaimana disajikan pada tabel 
kriteria berikut. Produk yang dinilai dikatakan baik atau valid apabila kriteria yang didapatkan adalah Baik atau Sangat Baik.

Pada penelitian pengembangan ini, peneliti memberi nilai kelayakan produk multimedia pembelajaran hasil pengembangan minimal "B" dengan katagori "Baik", sehingga hasil penilaian, baik dari ahli materi maupun ahli media dan juga siswa, jika sudah memberikan penilaian akhir (keseluruhan) dengan nilai minimal "B", maka produk multimedia pembelajaran hasil pengembangan tersebut sudah dianggap layak untuk digunakan.

\section{Teknik Analisis Data Kevalidan}

Data berupa skor penilaian dari validator yang diperoleh dalam bentuk kategori yang terdiri dari lima pilihan penilaian tentang kualitas produk media pembelajaran matematika virtual berbasis TGT yang dikembangkan, yaitu sangat baik (5), baik (4), cukup (3), kurang (2) dam sangat kurang (1). Data tersebut diubah menjadi data interval.

Penilaian ahli materi dilakukan oleh satu penilai dengan banyak item penilaian untuk ahli materi yaitu 14 item. Dengan demikian dapat diperoleh skor minimum ideal $=14$, skor maksimum ideal $=80, \bar{x}_{\mathrm{i}}=48$ dan SBi $=10,67$. Sedangkan Penilaian ahli media dilakukan oleh satu penilai dengan banyak item penilaian untuk ahli media yaitu 9 item. Dengan demikian dapat diperoleh skor minimum ideal $=9$, skor maksimum ideal $=65, \bar{x}_{\mathrm{i}}=39$ dan $\mathrm{SBi}=8,67$. sehingga diperoleh kriteria interval sebagai berikut.

Tabel 1. Kriteria Interval Kevalidan

\begin{tabular}{|c|c|c|c|}
\hline Interval & & & \\
\hline $\begin{array}{c}\text { Kriteria } \\
\text { Materi }\end{array}$ & $\begin{array}{c}\text { Kriteria } \\
\text { Media }\end{array}$ & Vilai & Kateo \\
\hline$X>67,206$ & $X>54,606$ & A & $\begin{array}{c}\text { Sangat } \\
\text { Baik }\end{array}$ \\
\hline $54,402<X \leq 67,206$ & $44,202<X \leq 54,606$ & B & Baik \\
\hline $41,598<X \leq 54,402$ & $33.798<X \leq 44,202$ & $\mathrm{C}$ & Cukup \\
\hline $28,794<X \leq 41,598$ & $23,394<X \leq 33,798$ & $\mathrm{D}$ & Kurang \\
\hline$X \leq 28,794$ & $X \leq 23,394$ & $\mathrm{E}$ & $\begin{array}{l}\text { Sangat } \\
\text { Kurang }\end{array}$ \\
\hline
\end{tabular}

Media pembelajaran matematika virtual berbasis TGT yang dihasilkan dikatakan baik jika minimal tingkat kualitas untuk masing masing kriteria yang dicapai adalah kategori baik.

\section{Teknik Analisis Data Kepraktisan}

Data kepraktisan media pembelajaran matematika virtual berbasis TGT diperoleh dari penilaian siswa terhadap media pembelajaran matematika interaktif. Kepraktisan media pembelajaran matematika virtual berbasis TGT yang dikembangkan diukur berdasarkan hasil penilaian dari siswa yang menggunakan produk pada saat uji coba. Skor penilaian yang diperoleh dari siswa dikonversikan menjadi data kualitatif skala lima. Penilaian siswa dilakukan oleh 64 penilai dengan banyak item penilaian untuk siswa yaitu 10 item. Dengan demikian dapat diperoleh 
Vol. 2, No. 1, Oktober 2017, pp. 57-68

skor minimum ideal $=168$, skor maksimum ideal $=840, \bar{x} i=504$ dan $S B i=112$. Sehingga, diperoleh kriteria interval sebagai berikut.

Tabel 2. Kriteria Interval Kepraktisan

\begin{tabular}{lcc}
\hline $\begin{array}{c}\text { Kriteria } \\
\text { Materi }\end{array}$ & Nilai & Kategori \\
\hline 206 & A & $\begin{array}{c}\text { Sangat } \\
\text { Baik }\end{array}$ \\
$<X \leq 67,206$ & B & Baik \\
$<X \leq 54,402$ & C & Cukup \\
$<X \leq 41,598$ & D & Kurang \\
, 794 & E & Sangat \\
& & Kurang
\end{tabular}

Media pembelajaran matematika virtual berbasis TGT yang dikembangkan dikatakan praktis jika penilaian kepraktisan media pembelajaran matematika virtual berbasis TGT yang dikembangkan oleh siswa konsisten minimal tingkat kualitas untuk masing masing kriteria yang dicapai adalah kategori baik.

\section{Teknik Analisis Data Keefektifan}

Analisis terhadap keefektifan media pembelajaran matematika virtual berbasis TGT dilakukan terhadap cognitive load theory. Media pembelajaran yang dikembangkan dikatakan efektif jika hasil dari tes secara signifikan atau minimal skor yang dicapai menunjukkan persentase ketuntasan minimal $75 \%$.

\section{Hasil Penelitian dan Pembahasan}

Prosedur Pengembangan

Pengembangan media pembelajaran matematika virtual berbasis TGT dikembangkan dengan beberapa tahapan. Adapun tahapan-tahapan tersebut adalah sebagai berikut:

a. Tahap I

1) Menganalisis standar kompetensi menggunakan bangun ruang sisi datar dalam pemecahan masalah yang berkaitan dengan balok, kubus, Prisma dan Limas untuk disampaikan melalui multimedia pembelajaran. Proses ini meliputi kajian materi matematika yang sesuai dengan standar isi.

2) Mengumpulkan referensi mengenai materi pokok Bangun Ruang Sisi Datar. Pemilihan standar kompetensi menggunakan BRSD dalam pemecahan masalah yang berkaitan dengan mengidentifikasi unsur, luas dan volume BRSD karena pada standar kompetensi tersebut hasil belajar siswa masih banyak yang masih dibawah KKM (hasil pra survei yang dilakukan di SMP N 1 Sedayu Bantul). Selain itu, nilai ujian nasional (UN) di 
SMP N 1 Sedayu pada standar kompetensi tersebut selama tiga tahun terakhir mengalami penurunan (laporan BSNP).

3) Merencanakan dan memilih jenis media pembelajaran yang akan digunakan. Multimedia pembelajaran yang dipilih yaitu berupa CD pembelajaran yang dapat digunakan dengan perangkat komputer. Pemilihan ini dikarenakan pengemasan dalam bentuk CD sangat efektif karena mempunyai memori yang cukup besar dan tidak mudah terhapus, selain itu multimedia pembelajaran ini dibuat menggunakan program Adobe Flash CS 5 yang penggunaannya harus menggunakan komputer.

b. Tahap II

Pembuatan multimedia pembelajaran ini membahas tentang standar kompetensi menggunakan bangun ruang sisi datar. Tahap ini merupakan desain awal pembuatan multimedia pembelajaran matematika yang dikembangkan. Desain tersebut menggambarkan alur halaman yang tersedia pada multimedia mulai dari halaman pembuka hingga halaman penutup. Pembuatan multimedia pembelajaran matematika mengacu pada desain ini

\section{Pembahasan}

Untuk menganalisis kevalidan produk digunakan dua data, yaitu penilaian ahli materi dan pembelajaran matematika, dan penilaian ahli media terhadap media pembelajaran matematika virtual berbasis TGT.

\section{Tabel 3.}

Data Skor Kevalidan Media Pembelajaran Matematika Virtual Berbasis Teams Game Tournament

\begin{tabular}{llrl}
\hline No & \multicolumn{1}{c}{ Aspek } & Skor & Kategori \\
\hline 1 & Materi dan & 60,33 & Sangat \\
& $\begin{array}{l}\text { Pembelajaran } \\
\text { Matematika }\end{array}$ & & \\
2 & Media Virtual & 39,5 & $\begin{array}{l}\text { Sangat } \\
\text { Baik }\end{array}$ \\
\hline
\end{tabular}

Dari Tabel 3 di atas skor diperoleh untuk kevalidan produk dari aspek materi dan pembelajaran matematika yaitu 60,33, dimana berada pada rentang skor di atas 56 sehingga kevalidan produk dari aspek materi dan pembelajaran matematika termasuk kategori sangat baik. sedangkan skor kevalidan yang diperoleh dari aspek media yaitu 39,5 yang berada pada rentang 36 , sehingga kevalidan produk dari aspek media termasuk dalam kategori sangat baik.

Penilaian kevalidan produk dari ahli materi dan pembelajaran dan ahli media secara konsisten menyatakan sangat baik. Oleh karena itu, dari data yang diperoleh dari penilaian oleh ahli materi dan pembelajaran matematika, dan ahli media dapat disimpulkan bahwa produk yang dikembangkan yaitu berupa multimedia pembelajaran matematika dapat dinyatakan sangat valid sehingga layak digunakan. 
Analisis Kepraktisan Multimedia Pembelajaran Matematika

Untuk mengetahui kepraktisan produk yang dikembangkan data yang digunakan adalah data tentang penilaian guru dan siswa terhadap multimedia pembelajaran matematika. Berdasarkan lembar angket yang diberikan kepada 64 siswa dan 1 guru matematika, diperoleh data tentang penilaian siswa dan guru terhadap multimedia pembelajaran matematika seperti telah disajikan pada tabel 4 berikut ini:

Tabel 4. Data Skor Kepraktisan Multimedia Pembelajaran Matematika

\begin{tabular}{clcl}
\hline No & Penilai & Skor & Kategori \\
\hline 1 & Siswa & 201,6 & Sangat Baik \\
2 & Guru & 3,9 & Baik \\
\hline
\end{tabular}

Dari Tabel 4 di atas skor yang diperoleh untuk kepraktisan produk berdasarkan penilaian siswa yaitu 201,6 yang berada pada rentang skor di atas 196 sehingga kepraktisan produk berdasarkan penilaian siswa termasuk kategori sangat baik. sedangkan skor kepraktisan yang diperoleh dari penilaian guru yaitu 3,9 yang berada pada rentang 3,33-4, sehingga kepraktisan produk berdasarkan penilaian guru termasuk dalam kategori baik.

Penilaian kepraktisan produk dari siswa dan guru secara konsisten menyatakan baik. Oleh karena itu, dari data yang diperoleh dari penilaian siswa dan guru dapat disimpulkan bahwa produk yang dikembangkan yaitu berupa multimedia pembelajaran matematika dapat dinyatakan praktis sehingga layak digunakan.

\section{Analisis Keefektifan Multimedia Pembelajaran Matematika}

Untuk mengetahui keefektifan media pembelajaran matematika virtual berbasis TGT yang dikembangkan digunakan instrumen tes cognitive load theory. Berdasarkan data hasil tes siswa kelas VIII, sebanyak 64 siswa diperoleh hasil analisis seperti pada table 5 berikut:

\section{Tabel 5. Analisis Data Tes Cognitive Load Theory}

\begin{tabular}{lcc}
\hline Jenis Tes & $\begin{array}{c}\text { Jumlah } \\
\text { siswa yang } \\
\text { tuntas }\end{array}$ & $\begin{array}{c}\text { Persentase } \\
\text { siswa yang } \\
\text { tuntas }\end{array}$ \\
\hline $\begin{array}{l}\text { Cognitive } \\
\text { Load Theory }\end{array}$ & 53 & $82,81 \%$ \\
\hline
\end{tabular}

Berdasarkan tabel 5 diatas Persentase ketuntasan siswa yaitu 82,81\%. Hal ini menunjukkan bahwa ketuntasan individu siswa telah mencapai batas minimum ketuntasan yaitu $75 \%$. Sehingga dapat disimpulkan bahwa produk yang dikembangkan efektif ditinjau dari Cognitive Load Theory.

\section{Kajian Produk Akhir}

Setelah dilakukan serangkaian tahap pengembangan, diperoleh produk akhir yang berupa media pembelajaran matematika virtual berbasis TGT yang memuat standar kompetensi Memahami sifat-sifat kubus, balok, prisma, limas, dan bagian-bagiannya, serta menentukan 
ukurannya. Produk tersebut telah dinyatakan valid, praktis, dan efektif melalui analisis yang dilakukan terhadap data-data yang diperoleh.

Produk yang dikembangkan ini telah melalui proses validasi dan penilaian dengan melakukan revisi sebanyak 3 kali. media pembelajaran matematika virtual berbasis TGT ini juga ditujukan untuk meningkatkan Cognitive Load Theory (CLT) dalam belajar matematika. Kualitas produk yang dikembangakn sjuga dinyatakan sangat baik berdasarkan penilai ahli materi dan pembelajaran matematika, ahli media dan siswa sehingga layak digunakan untuk skala yang lebih besar. Produk ini dirancang sebagai media pembelajaran yang dapat digunakan guru untuk menyampaikan materi dikelas. Produk media pembelajaran matematika virtual berbasis TGT juga dapat diakses di http://labpmat.mercubuana-yogya.ac.id.

\section{Kesimpulan}

Berdasarkan hasil penelitian dan pembahasan diperoleh simpulan sebagai berikut:

1. Produk yang dikembangkan berupa media pembelajaran matematika virtual berbasis TGT materi pokok bangun ruang sisi datar. Media pembelajaran matematika memuat 4 tingkatan dengan permainan Uno Beam Magic, dimana permainan ini juga terdapat soal-soal yang harus dikerjakan untuk naik ke level berikutnya. Produk ini telah diujicobakan di SMP Negeri 1 Sedayu kabupaten Bantul dan dapat diakses atau diunggah melalui laman http://labpmat.mercubuana-yogya.ac.id sehingga layak digunakan dalam kegiatan pembelajaran dengan skala yang lebih luas.

2. Hasil pengembangan yang berupa media pembelajaran matematika virtual berbasis TGT dinyatakan sangat valid berdasarkan penilaian ahli materi dan pembelajaran, dan ahli media. Penilaian ahli-ahli tersebut secara konsisten mengkategorikan media pembelajaran matematika virtual berbasis TGT dalam kategori sangat valid.

3. Hasil pengembangan yang berupa media pembelajaran matematika virtual berbasis TGT dinyatakan praktis berdasarkan penilaian guru dan siswa. Penilaian guru dan siswa secara konsisten mengkategorikan multimedia pembelajaran matematika dalam kategori praktis.

4. Hasil pengembangan yang berupa media pembelajaran matematika virtual berbasis TGT dinyatakan efektif berdasarkan hasil tes Cognitive Load Theory siswa. Dari hasil tes tersebut siswa secara konsisten menyatakan bahwa media pembelajaran matematika virtual berbasis TGT efektif ditinjau dari Cognitive Load Theory.

\section{Saran}

Berdasarkan kesimpulan yang dikemukakan di atas, maka beberapa saran yang perlu dipertimbangkan untuk peningkatan kualitas pembelajaran matematika sekolah sebagai berikut:

1. Produk yang dikembangkan ini dapat dijadikan sebagai contoh media pembelajaran matematika virtual yang interaktif yang dapat disebarluaskan serta menjadi bahan masukan para guru dalam kegiatan pembelajaran matematika yang memanfaatkan multimedia pembelajaran matematika. 
Vol. 2, No. 1, Oktober 2017, pp. 57-68

2. Perluasan materi pada pengembangan media pembelajaran matematika virtual, dengan memanfaatkan internet, sehingga kedepan media pembelajaran sudah dapat diakses lewat android dengan bantuan software Appy Pie atau Construct2.

\section{REFERENSI}

Brunning Scaw, Norby dan Ronning. (2004). Cognitive load theory, learning difficulty and instructional design. Learning and Instruction, 4 , 295-312.

BSNP. (2006). Panduan penyusunan kurikulum tingkat satuan pendidikan jenjang pendidikan dasar dan menengah. Jakarta: Badan Standar Nasional Pendidikan.

Geisert, Paul G \& Mynga. 1995. Teachers, Computers and Curriculum: Microcomputers in the classroom. United State of America: Allyn \& Bacon.

Kemp, E. J. (1994). Instructional design: a plan for unit and course development (2nd ed). New York: Merril.

Lee, W., \& Owens, D. (2004). Multimedia based instructional design. San Fransisco: Preiffer.

Mukminan. (2004). Desain Pembelajaran. Yogyakarta: Universitas Negeri Yogyakarta.

Munir. 2008. Kurikulum Berbasis Teknologi Informasi dan Komunikasi. Bandung:Alfabeta.

Nieveen, N. (1999). Prototyping to Reach Product Quality dalam Plomp, T; Nieveen, N., Gustafson, K., Branch, R. M., \& van den Akker, J (eds). Design approaches and tools in education and training. London: Kluwer Academic Publisher.

Nurfitri R. (2015). Pengembangan Media Pembelajaran Uno Beam Magic Pada Materi Logika Matematika Untuk Siswa Kelas X SMA. Malang: Universitas Islam Malang.

Pustekkom. (2004). Modul Serial Pelatihan Pengembangan Multimedia Interaktif. Jakarta: Pustekkom. Diknas.

Romi Satria Wahono. (2006). Aspek dan kriteria penilaian media pembelajaran. Diambil tanggal 23 April 2016 dari http://romisatriawahono.net/?p=170.

Slavin, R.E. (2008) Cooperatif learning. (Terjemahan Zubaedi). Bandung: Misan Nusa Media. (Buku asli diterbitkan tahun 2005).

Sugiman. (2013). Pengembangan Laboratorium Pendidikan Matematika Virtual:Adaptive ELearning dan Cognitive Load Theory. Yogyakarta: Universitas Negeri Yogyakarta.

Sweller, J. (1999). Instructional Design in Technical Areas. Victoria, Australia: Australian Council for Educational Research.

Sweller, J. (2004). Instructional Design Consequences of an Analogy between Evolution by Natural Selection and Human Cognitive Architecture. Instructional Science, 32(1-2), 9-31.

Sweller, J. (2010). Element Interactivity and Intrinsic, Extraneous, and Germane Cognitive Load. Educational Psychology Review, 22(2), 123-138. 

Vol. 2, No. 1, Oktober 2017, pp. 57-68 